\title{
Specific Binding of Endothelin on Human Vascular Smooth Muscle Cells in Culture
}

Martine Clozel, Walter Fischli, and Claire Guilly

Pharmaceutical Research Department, F. Hoffmann-La Roche \& Co., Ltd., CH-4002 Basle, Switzerland

\begin{abstract}
Endothelin is a newly discovered, potent vasoconstrictor peptide secreted by endothelial cells. The binding of endothelin was studied on cultured human vascular smooth muscle cells obtained from umbilical veins. A single specific binding site for ${ }^{125}$ I-endothelin was identified, with an apparent $K_{\mathrm{d}}$ of $126 \mathrm{pM}$ and a maximal binding capacity of $\sim 10,000$ sites per smooth muscle cell. At room temperature the binding was saturable, reached equilibrium at $2 \mathrm{~h}$ (using $20 \mathrm{pM}$ endothelin), and was slowly and only partially reversed by unlabeled endothelin. The calcium antagonists nifedipine, nicardipine, and diltiazem did not compete for the same binding site. Conditioned medium from cultured human umbilical vein endothelial cells inhibited the binding of ${ }^{125} \mathrm{I}$-endothelin dose dependently. This effect was antagonized by anti-endothelin antiserum. We conclude that human umbilical vein smooth muscle cells possess specific binding sites for endothelin, and that human endothelial cells secrete an endothelinlike material.
\end{abstract}

\section{Introduction}

Endothelin is a potent vasoconstrictor peptide secreted by endothelial cells (1). Human endothelin, cloned from a placenta cDNA library, and porcine endothelin, isolated from supernatant of cultured porcine endothelial cells, have identical sequences (2).

Endothelin is a 21 amino acid peptide with two disulfide bridges that cannot be placed in any known family among the mammalian peptides, but has a strong homology with sarafotoxin S6, a group of 21-residue cardiotoxic peptides isolated from snake venom (3). Since it had also some homology with neurotoxins acting on tetrodotoxin-sensitive $\mathrm{Na}^{+}$channels, which resemble the dihydropyridine-sensitive $\mathrm{Ca}^{2+}$ channels, and since the vasoconstrictor activity of endothelin was inhibited by nicardipine, it was suggested that endothelin might be an endogenous agonist of the dihydropyridine-sensitive $\mathrm{Ca}^{2+}$ channels (1). In the present study we have identified and characterized specific binding sites for endothelin on cultured human smooth muscle cells. The binding of endothelin was

Address correspondence to Dr. Martine Clozel, Pharmaceutical Research Department, F. Hoffmann-La Roche \& Co., Ltd., CH-4002 Basle, Switzerland.

Received for publication 21 September 1988 and in revised form 4 January 1989.

J. Clin. Invest.

(C) The American Society for Clinical Investigation, Inc.

0021-9738/89/05/1758/04 \$2.00

Volume 83, May 1989, 1758-1761 inhibited by conditioned medium from human endothelial cells, suggesting that human endothelial cells in culture secrete an endothelinlike material.

\section{Methods}

Materials. Endothelin was purchased from Peninsula Laboratories, Inc. (Belmont, CA). Endothelin was trace-labeled with carrier-free ${ }^{125}$ I by the lactoperoxidase method at Anawa Laboratories (Wangen, Switzerland). The nonoxidized mono-iodinated [3-( $\left.\left.{ }^{125} \mathrm{I}\right) \mathrm{Tyr}\right]-\mathrm{endothelin}$ was purified by HPLC. The specific radioactivity was $2,200 \mathrm{Ci} / \mathrm{mmol}$.

All culture reagents were from Gibco Laboratories (Paisley, Scotland) and the culture flasks and plates from Costar (Cambridge, MA). Collagenase (CLS II) was from Worthington Biochemical Corp. (Freehold, NJ). SDS and EDTA were from Fluka AG (Buchs, Switzerland), and Sep-Pak cartridges from Waters Associates (Milford, MA). The anti- $\alpha$-smooth muscle cell actin antibody was a kind gift of Dr. G. Gabbiani (University of Geneva, Geneva, Switzerland), and fluorescein-conjugated goat anti-mouse antibody was from Dakopatts (Glostrup, Denmark). Nifedipine (Sigma Chemical Co., St. Louis, MO) was dissolved in ethanol to a $10^{-2} \mathrm{M}$ solution; nicardipine and diltiazem (Roche, Basle, Switzerland) were dissolved in DMSO. Further dilutions were made in DME. Care was taken to protect nifedipine- and nicardipine-containing solutions from light.

For immunoprecipitation, anti-endothelin rabbit antiserum was obtained from Peptide Institute (Osaka, Japan) and Immunobead Second Antibody Reagent from Bio-Rad Laboratories (Richmond, CA).

Cell culture. Human endothelial cells were obtained from umbilical veins and cultured as described by Jaffe (4). The cells were harvested after the vein had been filled for $12 \mathrm{~min}$ with collagenase ( 2 $\mathrm{mg} / \mathrm{ml}$ ) in HBSS. They were grown to confluence on plastic flasks in RPMI 1640 supplemented with $20 \%$ FCS in a volume of $\sim 1 \mathrm{ml}$ for 2 $\times 10^{5}$ cells.

The conditioned medium was collected every $48 \mathrm{~h}$. Conditioned medium was centrifuged $(1,000 \mathrm{~g}, 10 \mathrm{~min})$ and concentrated by extraction through a $\mathrm{C}_{18}$ Sep-Pak cartridge conditioned with acetonitrile containing $5 \mathrm{mM}$ trifluoracetic acid. The retained material was eluted with methanol, evaporated, and resuspended in binding medium. The volumes given in the text and figures are the volumes of conditioned medium before extraction.

Human vascular smooth muscle cells were obtained and cultured as described $(4,5)$. Briefly, after a first incubation with collagenase to remove endothelial cells, the umbilical vein was filled again with collagenase for $45 \mathrm{~min}$. Smooth muscle cells were grown to confluence in plastic flasks or 24-well plates in DME supplemented with 10\% FCS.

Smooth muscle cells were subcultured after trypsinization (the cell detachment after trypsin-EDTA was followed by microscopy and the trypsin was immediately neutralized by adding DME $+10 \%$ FCS). The cells were used between passages 4 and 6 . They were identified by their typical "hill-and-valley" morphology and by immunofluorescence using a MAb against $\alpha$-smooth muscle actin, which is a specific marker of differentiated smooth muscle cells (6). Fluorescein-conjugated goat anti-mouse antibody was used as a second antibody. All the cells were labeled by the antibodies (Fig. 1). 
Binding studies. Confluent human smooth muscle cells in 16-mmdiam wells $\left(\sim 7 \times 10^{4}\right.$ cells/well $)$ were washed three times with DME containing $2 \mathrm{mg} / \mathrm{ml} \mathrm{BSA}$ and $25 \mathrm{mM}$ Hepes (binding medium), and incubated at room temperature with $500 \mu \mathrm{l}$ binding medium containing radiolabeled endothelin. At the end of the incubation period the cells were solubilized in $1 \%$ SDS with $0.5 \mathrm{M}$ sodium hydroxide and $0.01 \mathrm{M}$ EDTA at $37^{\circ} \mathrm{C}$, and the radioactivity of bound ${ }^{125} \mathrm{I}$-endothelin was measured. The radioactivity of unbound endothelin was calculated as radioactivity added minus radioactivity bound. Nonspecific binding was determined in parallel and defined as binding in the presence of $100 \mathrm{nM}$ unlabeled endothelin. Specific binding was calculated as total binding minus nonspecific binding.

Immunoprecipitation. Extracts of conditioned medium were incubated for $20 \mathrm{~min}$ with anti-endothelin rabbit antiserum at a fina dilution of 1:1,000. Such a dilution of antiserum had been shown in preliminary experiments to prevent the binding of $20 \mathrm{pM}^{125}$ I-endothelin by $70 \%$. The Immunobead Second Antibody was then added (3.3 $\mathrm{mg} / 500 \mu \mathrm{l}$ of 1:1,000 dilution of antiserum) and incubated for $2 \mathrm{~h}$ at $37^{\circ} \mathrm{C}$. The immune complexes were precipitated by centrifugation ( 7 min at $1,000 \mathrm{~g}$ ) and the supernatant was used in competition experiments. Competition experiments with conditioned medium that had not been treated with antiserum were performed in parallel.

\section{Results}

Kinetics of the binding. The binding of ${ }^{125}$ I-endothelin to cultured human smooth muscle cells reached an apparent equilibrium after $2 \mathrm{~h}$ (Fig. $2 \mathrm{~A}$ ). In all subsequent experiments, therefore, the incubation time of smooth muscle cells with labeled endothelin was $2 \mathrm{~h}$. The binding of ${ }^{125} \mathrm{I}$-endothelin was only partially reversed by addition of $10 \mu \mathrm{M}$ unlabeled endothelin. At $24 \mathrm{~h}$ the binding of ${ }^{125} \mathrm{I}$-endothelin was still $53 \%$ of maximal binding (Fig. $2 \mathrm{~B}$ ). The dissociation of ${ }^{125} \mathrm{I}$-endothelin displayed a biphasic curve when analyzed by logarithmic transformation and linear regression. Typical estimates of fast and slow dissociation half-lives were 5 and $69 \mathrm{~h}$, respectively.

Saturation experiments. The specific binding of ${ }^{125} \mathrm{I}$-endothelin to smooth muscle cells was saturable, as shown in Fig. 3. Scatchard analysis indicated the existence of a single population of binding sites. The calculated equilibrium $K_{\mathrm{d}}$ was 126 $\mathrm{pM}$ and the maximal binding capacity was $16.9 \mathrm{fmol} / 10^{6}$ cells, i.e., 10,180 binding sites per cell.

Competition experiments. The binding of ${ }^{125} \mathrm{I}$-endothelin was inhibited by unlabeled endothelin, with a half-maximal inhibition concentration of 212 pM (Fig. 4). Conditioned medium from cultured human endothelial cells also completely inhibited ${ }^{125}$ I-endothelin binding (Fig. 4). The volume of conditioned medium (before extraction) that inhibited the binding by $50 \%$ was $270 \mu$ l. Thus, the concentration of endothelinlike material in conditioned medium from endothelial cells could be calculated to be $\sim 395 \mathrm{pM}$, or $1 \mathrm{ng} / \mathrm{ml}$. To evaluate whether the factor in conditioned medium that competed with ${ }^{125}$ I-endothelin for binding was immunologically related to endothelin, immunoprecipitation with anti-endothelin rabbit antiserum and Immunobead Second Antibody was performed. After immunoprecipitation, the supernatant of conditioned medium up to a volume of $200 \mu$ l did not compete with the binding of ${ }^{125}$ I-endothelin (Fig. 4).

The binding of ${ }^{125}$ I-endothelin was inhibited neither by nifedipine, nicardipine, nor diltiazem when added in concentrations up to $10 \mu \mathrm{M}$ (Fig. 5).

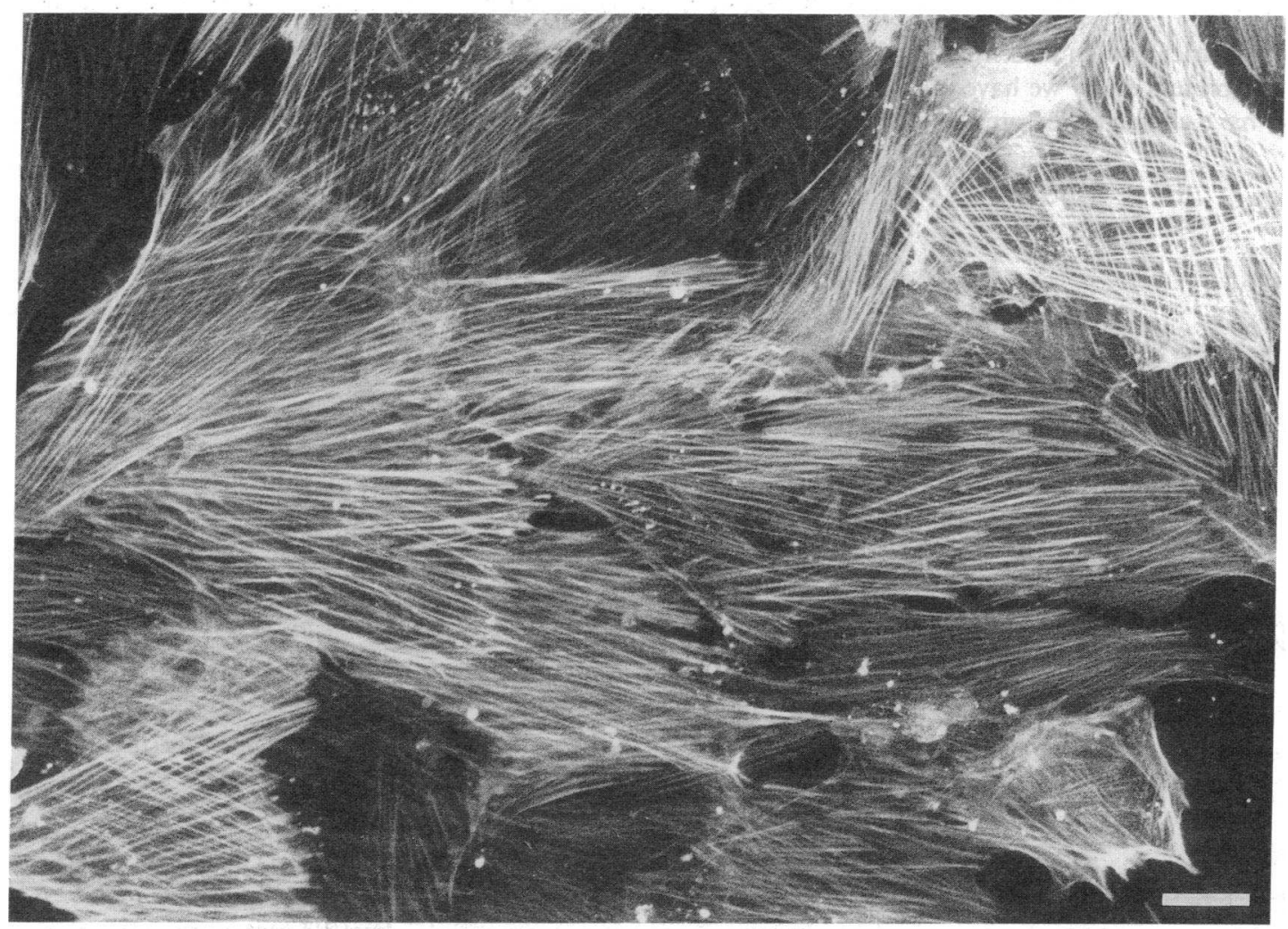

Figure 1. Immunofluorescent staining of human smooth muscle cells in culture with anti- $\alpha$-smooth muscle actin antibody. Fluorescein-conjugated goat anti-mouse antibody was used as a second antibody. Stress fibers are clearly seen in the cells that form multilayers. Bar $=35 \mu \mathrm{m}$. 
A

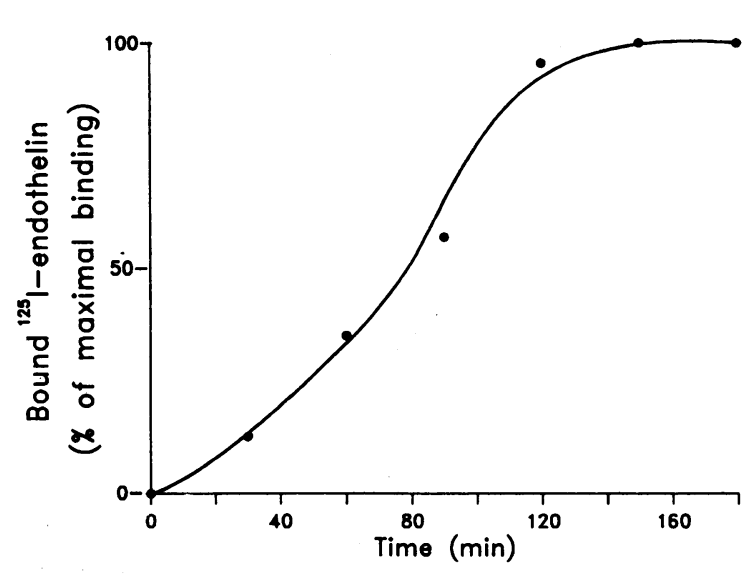

B

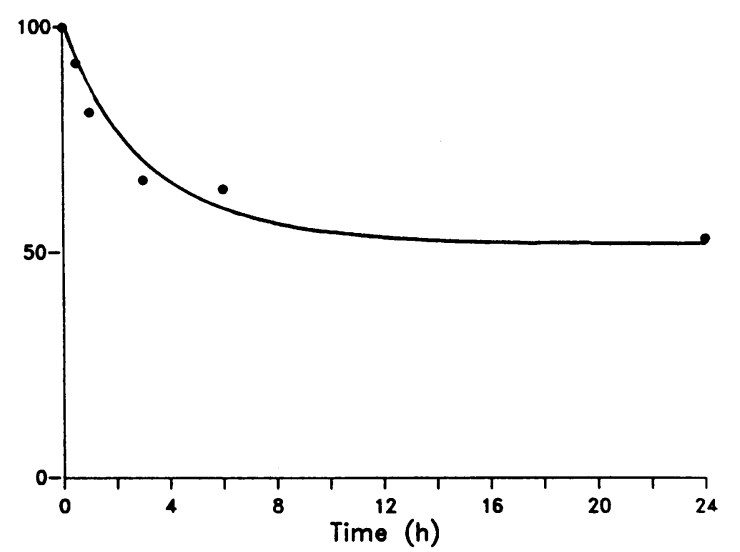

Figure 2. Association $(A)$ and dissociation $(B)$ curves of ${ }^{125} \mathrm{I}$-endothelin to human smooth muscle cells. $(A)$ Cells were incubated with 20 pM ${ }^{125} \mathrm{I}$-endothelin for various times with or without $100 \mathrm{nM}$ unlabeled endothelin. The percentage of specific binding is shown as a function of time. (B) After $2 \mathrm{~h}$ of incubation with $20 \mathrm{pM}^{125}$ I-endothelin, $10 \mu \mathrm{M}$ unlabeled endothelin was added. The percentage of remaining specific binding is given as a function of time. Each point in $A$ and $B$ represents the mean of duplicate experiments.

\section{Discussion}

The results of the present study show that human vascular smooth muscle cells cultured from umbilical veins possess a single class of specific binding sites for endothelin.

The binding of endothelin to human cultured smooth muscle cells is of high affinity, specific, and saturable within 2 $h$. The dissociation of labeled endothelin after addition of unlabeled endothelin is biphasic. The second and slow phase might be due to a very tight binding and/or internalization of the receptor.

Endothelin is able to constrict human mesenteric and pulmonary arteries (1). In the present study we have not proven that the binding sites we have characterized are the receptors by which endothelin exerts its potent vasoconstrictor effect. However, the very strong interaction of endothelin with its binding site (high affinity, slow displacement) might explain the extremely prolonged effect of endothelin in different vascular beds $(1,7)$.

The binding site of endothelin to human smooth muscle cells is not a binding site for dihydropyridines, since nifedipine and nicardipine did not compete with the binding of endothelin. This, however, does not rule out the possibility that endothelin is an endogenous modulator of voltage-dependent $\mathrm{Ca}^{2+}$ channels (1).

Endothelin has been isolated from supernatant of porcine aortic endothelial cells (1), and its existence has been suggested in supernatants of bovine aortic endothelial cells $(8,9)$.

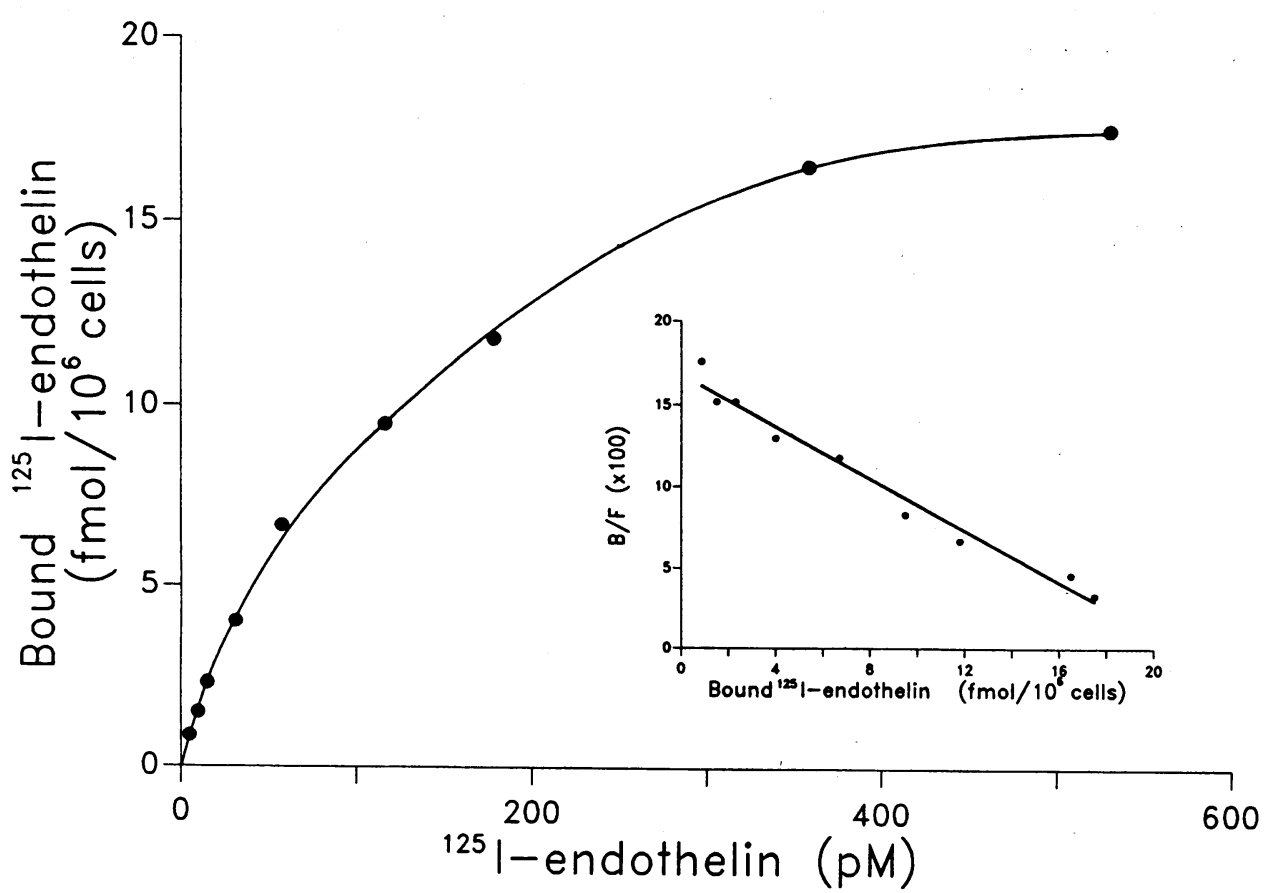

Figure 3. Specific binding of ${ }^{125}$ I-endothelin to smooth muscle cells as a function of ${ }^{125}$ I-endothelin concentration. Smooth muscle cells were incubated for $2 \mathrm{~h}$ with different concentrations of ${ }^{125}$ I-endothelin in the presence or absence of $100 \mathrm{nM}$ unlabeled endothelin. (Inset) Scatchard analysis of ${ }^{125}$ I-endothelin specific binding gave a straight line $(r=0.99)$ from which the $K_{\mathrm{d}}$ and maximum binding capacity were calculated to be $126 \mathrm{pM}$ and 16.9 $\mathrm{fmol} / 10^{6}$ cells, respectively. Each point represents the mean of duplicate experiments. 


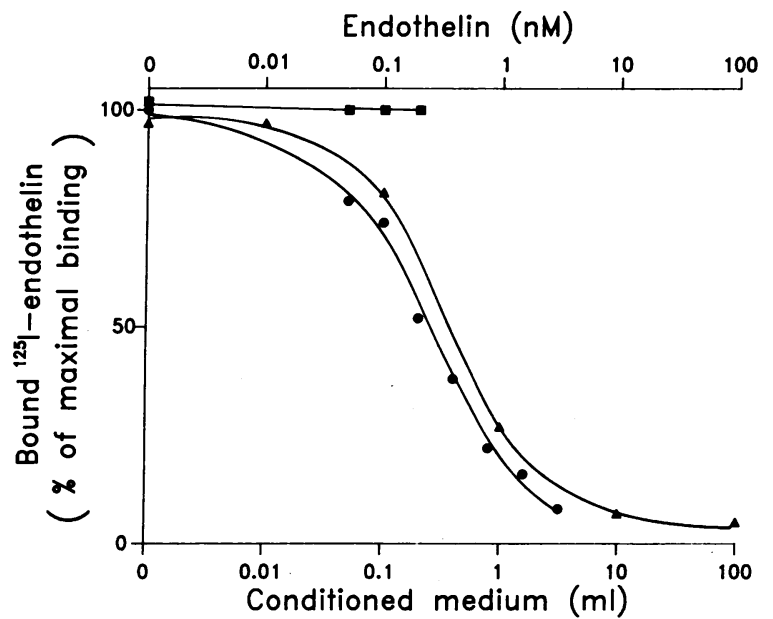

Figure 4. Inhibition of the binding of ${ }^{125}$ I-endothelin to cultured smooth muscle cells by unlabeled endothelin or conditioned medium from cultured human endothelial cells. Smooth muscle cells were incubated for $2 \mathrm{~h}$ with $20 \mathrm{pM}^{125}$ I-endothelin in the presence of increasing concentrations of unlabeled endothelin $(\Delta)$ or of extracts of increasing volumes of conditioned medium from endothelial cells $(\bullet)$, or after the extracts had been subjected to immunoprecipitation with anti-endothelin rabbit antiserum and Immunobead Second Antibody ( $\boldsymbol{\omega})$. Each point represents the mean of triplicate experiments.

Human endothelin has finally been cloned from a placenta cDNA library (2). However, the secretion of endothelin by human endothelial cells has not been reported until now. We present here the first argument for the presence of an endothelinlike, immunoprecipitable material in conditioned medium of cultured human endothelial cells.

While we were performing this study a paper was published on the specific binding of endothelin on rat vascular smooth

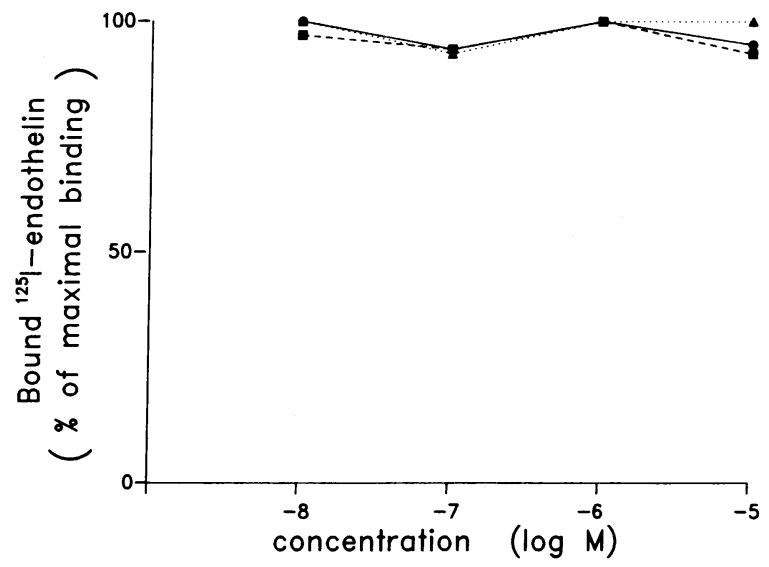

Figure 5. Effect of nifedipine $(\cdots . \cdots)$, nicardipine $(-\bullet-)$, and diltiazem (-- --) on the binding of $20 \mathrm{pM}^{125}$ I-endothelin. The three calcium entry blockers were added in increasing concentrations at the same time as ${ }^{125}$ I-endothelin. Each point represents the mean of triplicate experiments. muscle cells in culture (10). Endothelin binds to these cells with an apparent $K_{d}$ of $200-400 \mathrm{pM}$ and a maximal binding capacity of $11,000-13,000$ sites/cell. This suggests a close homology between human and rat smooth muscle cell receptor for endothelin.

In conclusion, endothelin binds specifically to human vascular smooth muscle cells. The binding site is distinct from the dihydropyridine binding site. The mechanisms involved in the potent vasoconstrictor effect of endothelin are still to be identified.

\section{Acknowledgments}

We wish to thank Dr. Günther Fischer for his help in immunohistochemistry, Ms. Laurence Müller for her technical assistance, Prof. Hans Rudolf Baumgartner and Dr. Wolfgang Osterrieder for their critical reading, and Mrs. Anna Weiss and Mrs. J. Lobsiger for typing the manuscript.

\section{References}

1. Yanagisawa, M., H. Kurihara, S. Kimura, Y. Tomobe, M. Kobayashi, Y. Mitsui, Y. Yazaki, K. Goto, and T. Masaki. 1988. A novel potent vasoconstrictor peptide produced by vascular endothelial cells. Nature (Lond.). 332:411-415.

2. Itoh, Y., M. Yanagisawa, S. Ohkubo, C. Kimura, T. Kosaka, A. Inoue, N. Ishida, Y. Mitsui, H. Onda, M. Fujino, and T. Masaki. 1988. Cloning and sequence analysis of cDNA encoding the precursor of a human endothelium-derived vasoconstrictor peptide, endothelin: identity of human and porcine endothelin. FEBS (Fed. Eur. Biochem. Soc.) Lett. 231:440-444.

3. Kloog, Y., I. Ambar, M. Sokolovsky, E. Kochva, Z. Wollberg, and A. Bdolah. 1988. Sarafotoxin, a novel vasoconstrictor peptide: phosphoinositide hydrolysis in rat heart and brain. Science (Wash. DC). 242:268-270.

4. Jaffe, E. A., R. L. Nachman, C. G. Becker, and C. R. Minick. 1973. Culture of human endothelial cells derived from umbilical veins. J. Clin. Invest. 52:2745-2756.

5. Gimbrone, M. A., Jr., and R. S. Cotran. 1975. Human vascular smooth muscle in culture. Lab. Invest. 33:16-27.

6. Skalli, O., P. Ropraz, A. Trzeciak, G. Benzonana, D. Gillessen, and G. Gabbiani. 1986. A monoclonal antibody against $\alpha$-smooth muscle actin: a new probe for smooth muscle differentiation. $J$. Cell Biol. 103:2787-2796.

7. Tomobe, Y., T. Miyauchi, A. Saito, M. Yanagisawa, S. Kimura, K. Goto, and T. Masaki. 1988. Effects of endothelin on the renal artery from spontaneously hypertensive and Wistar Kyoto rats. Eur. J. Pharmacol. 152:373-374.

8. Hickey, K. A., G. Rubanyi, R. J. Paul, and R. F. Highsmith. 1985. Characterization of a coronary vasoconstrictor produced by cultured endothelial cells. Am. J. Physiol. 248 (Cell Physiol. 17): C550C556.

9. O'Brien, R. F., R. J. Robbins, and I. F. McMurtry. 1987. Endothelial cells in culture produce a vasoconstrictor substance. J. Cell. Physiol. 132:263-270.

10. Hirata, Y., H. Yoshimi, S. Takata, T. X. Watanabe, S. Kumagai, K. Nakajima, and S. Sakakibara. 1988. Cellular mechanism of action by a novel vasoconstrictor endothelin in cultured rat vascular smooth muscle cells. Biochem. Biophys. Res. Commun. 154:868-875. 